\title{
Concomitance of Carcinoma With Hydatidosis in BALB/C Mice
}

\section{Entisar R. Al-Kennany \\ Department of Pathology}

College of Veterinary Medicine

Mosul University
Nabeel E. Salih

Department of Biology

College of Education

Mosul University
Buthaina H. Al- Sabawi

Department of Anatomy

Mosul College of Medicine

Mosul University
Received

29/10/2006
Accepted

09/01/2007

\section{الظلاصة}

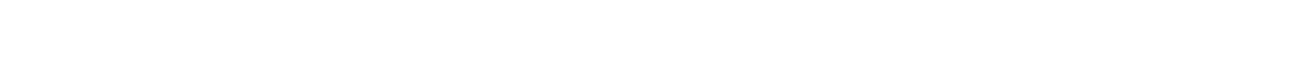

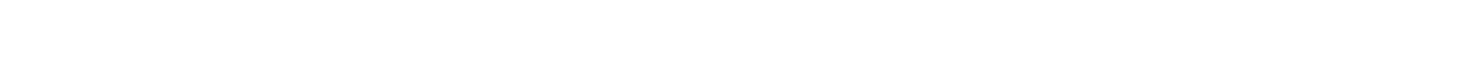

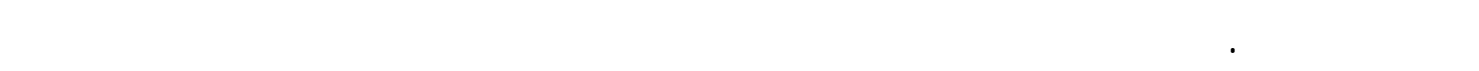

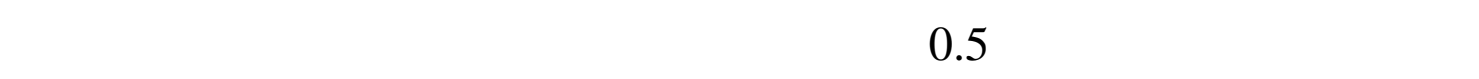

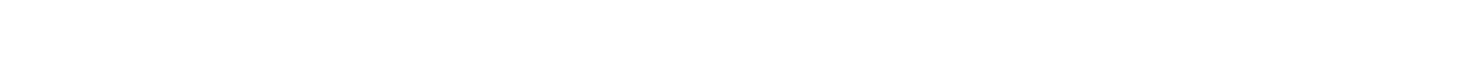
كونها اورله.

\section{ABSTRACT}

The present study aimed at investigation of the histopathological changes which may occur in mice due to experimental infection with protoscoleces of Echinococcus granulosus of different host origin.

Whitish-yellow nodules of different size, ranging between pinpoint and $0.5 \mathrm{~cm}$ in diameter, both solid and cystic in structure, were observed in the liver and spleen of the infected mice. Further investigation revealed that these nodules indicate that they are tumor cells.

\section{INTRODUCTION}

Cystic hydatid disease (CHD), caused by the larval stage of Echinococcus granulosus, is one of the most serious tapeworm infection in man (1) as well as more than 70 species of herbivores (2). Its importance is reflected by the fact that it is asymptomatic for 5-10 years post infection. The lack of an effective chemotheraputic agent makes surgery the only possible cure of the disease $(3,4)$, although surgery may be difficult to commence in some cases (5). In hydatid disease, the type 
and extent of pathological conditions depend on the location of the cyst in the host. As the size of the hydatid cyst increases, it crowds adjacent host tissues and interferes with their normal functions. The results may be very serious (6).

In this study, tumor nodules were observed in the liver and spleen of mice infected, intraperitoneally, with protoscoleces of E. granulosus of sheep and human origin. Appearance of these nodules and their nature are disscussed.

\section{MATERIALS AND METHODS}

Forty male, 3-4 weeks old, BALB/C mice, of the species Mus musculus, were used. They were divided into 3 groups (each group with 10 mice), group 1 (G1) is the control group. Group 2 (G2) was infected, intraperitoneally, with about 2000 protoscoleces of E. granulosus of sheep origin, whereas group 3 (G3) was infected with the same number of protoscoleces of human origin. Isolation of protoscoleces from hydatid cysts was carried out according to Smyth (7). Viability test and preparation for inoculation was commenced according to Smyth and Barrett (8). Protoscoloces with more than 90\% viability rate were used. Infected mice were sacrificed at 6 months post infection. Blood smears were taken before sacrificing, stained by Leishman stain (9) and were prepared for total leukocyte count (TLC) and differential leukocyte count (DLC). Phagocytic index was also studied using nitro blue tetrazolium (10). After removal of liver and spleen, gross and microscopic examinations for histopathological changes were carried out. Results were compared with those of the control group mice which were sacrified at the same time.

\section{Tissue preparation}

For histopathological changes, tissues were fixed in $10 \%$ neutral buffer formalin and processed, routinely, to paraffin sections. 4-6 $\mu \mathrm{m}$ thick sections were prepared and stained with hematoxyline-eosine stain (9).

\section{RESULTS}

A significant increase in TLC in infected mice was observed, compared with the control group. Considering the DLC, the significant increase was observed in all leukocytes compared with the control group, although it was more pronounced with the lymphocytes (Table 1).

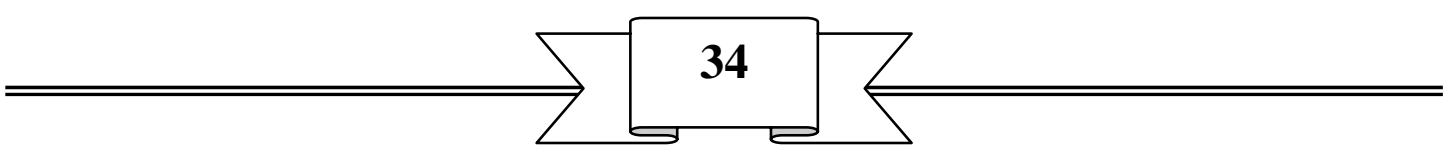


Table (2) shows the number of tumor nodules observed in infected mice associated with number of animals in which they were found and with the number of cysts. With cysts of both sheep and human origin, tumor nodules were observed in liver and spleen. However, number of nodules was significantly higher in mice infected with protoscoleces of sheep origin, compared with those infected with human origin.

\section{Gross appearance}

Hepatomegaly was observed in G2 and G3 mice associated with the presence of whitish-yellow nodules of different sizes, ranged between pinpoint and $0.5 \mathrm{~cm}$ in diameter, both solid and cystic in structure. In cut sections, white-firm paranchymal tissues were observed in the solid nodules whereas yellow with red pigments were found in the cystic nodules. The outer layer was fibrosed, represented by the capsule. The laminated layer appeared as white thick layer. The germinal layer appeared normal. The liver, as a whole, appeared deep red-brown in color. The gross appearance of spleen revealed splenomegaly, the spleen was deep red-brown in color and friable in consistency with some solid areas.

\section{Histopathological changes}

In liver, there was a loss in the architecture of the hepatic tissue, especially in the portal area. Liver had cystic structures consisting of daughter cysts surrounded by thick collagen fibers, with infiltration of inflammatory cells represented by plasmacytes, lymphocytes, macrophages, epithelioid cells, giant cells and eosinophils (Figs 1 and 2). Presence and absence of protoscoleces in the cysts was not followed.

In hepatic tissue, there was an evidence of tumor cells, appearing smaller or larger than hepatic cells, characterized by an arrangement in acinar pattern. Cells were seen with irregular dispersed chromatin and heavily stained nuclear membranes (hyperchromasia), prominent nucleoli, anaplastic trabecular carcinoma with bizarre hepatocytes, hypertrophy of Kupffer cells. The tumor cells of the noudles could also be seen in the cyst fluid and in the capsule. These tumor cells had a mitotic figure (mitosis). Tumor cells have also been seen. In sinusoids, thick trabeculae or an acinar pattern were seen, frequently, in the liver. There was hepatic cell carcinoma (adenocarcinoma) (Figs. 3-5).

In spleen, histopathological changes seen included expansion of the red pulp containing dense cluster of lymphoblastic-cystoid cells.

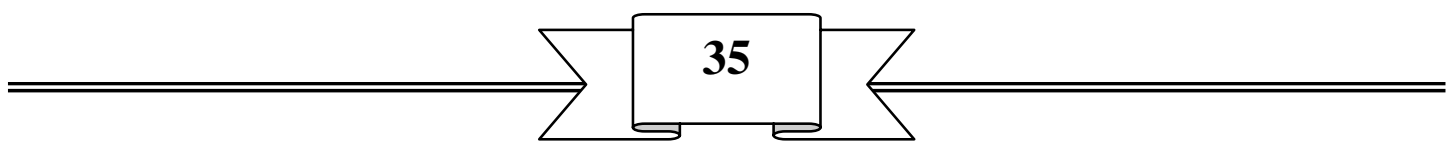


Eosinophilic myeloid cells and megakaryocytes were also found. Tumor cells, characterized by hyperchromasia and mitotic figure were also seen in the paranchyma of the spleen associated with tumor giant cells (Figs 6 and 7). Hemosiderin pigmentation was also observed.

\section{DISCUSSION}

The present study revealed an elevation in TLC and DLC in both groups of mice infected with protoscoleces of E. granulosus of sheep (G2) and human (G3) origin , compared with the control group. The elevation in DLC was more towards increase in the number of lymphocytes, followed by macrophages. This is expected as it is known that infection with protoscoleces of Echinococcus stimulates proliferation of lymphocytes and macrophages at its early stages of infection (11). However, Belding (12) have also previously mentioned that the unilocular cyst evokes an inflammatory reaction of the surrounding tissues that produces an encapsulating, fibrous adventitious layer. Immediately around the cysts, there is an infiltration of lymphocytes, eosinophils and giant cells surrounded by a zone of fibroblasts, new blood vessels and fibrous tissues. Proliferation of mononuclear cells in hydatid disease may be due, not only to promotion by protoscoleces, but to the effort of hydatid fluid consistency, particularly the antigen $\mathrm{BH}_{5}$, Sup, and $\mathrm{BH}_{5}$ PPT on the blood cells. Phagocytic index, on the other hand, is known to be a good immunological tool for cell mediated immunity (13). In the present study, the difference in the phagocytic index between G2 and G3 may be referred to strain variation of the parasite $(14,15)$.

In the present study, the accumulation of neutrophils could be explained by the fact that a 12KDa antigen in the hydatid fluid could have had the capacity to inhibit the enzyme protease, causing chemotaxis for neutrophils, as mentioned by Shepherd and McManus (16). In natural infection, this antigen interacts with the immunological response of the host, making permission for the parasite to persist for long periods in the host (17). In addition, protoscoleces could have comprised a cyclophillinlike gene, causing a cleft in the host proteins (18). This stimulation may well provide a good condition for anoxia, glycolysis, increased ammonia and release of toxic substances, leading to secondary pathological lesions. Taking this point of view into consideration, one might have a possible explanation for the occurrence of adenocarcinoma. On the other hand, chronic persistence of hydatid cysts in the canaliculi could have induced a chromic irritation in connection with other unknown substance, which could have led to a true induction of tumor. Whether there is a true

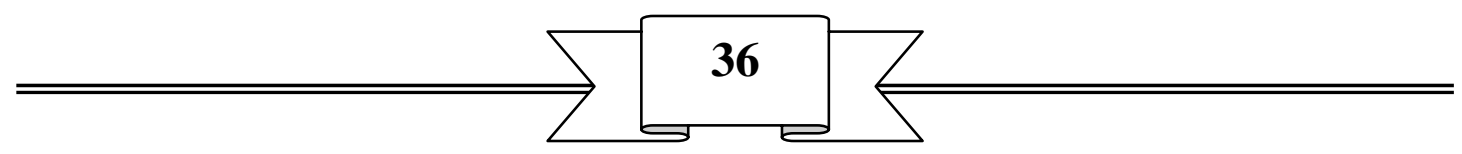


correlation between appearance of tumor nodules and infection with hydatid disease or not, needs further investigation.

Table (1). Differential leukocyte count (TLC) and phagocytic index in mice infected with secondary hydatid disease of sheep (G2) and human (G3) origin at 6 months post infection.

\begin{tabular}{|c|c|c|c|c|c|c|c|}
\hline Group & \multirow{2}{*}{ TLC } & \multicolumn{5}{|c|}{ DLC\% } & $\begin{array}{c}\text { Phagocytic } \\
\text { index }\end{array}$ \\
\cline { 3 - 8 } & & Neutrophils & Eosinophils & Basophils & Lymphocytes & Monocytes & $11 \%$ \\
\hline G1 & 8493 & 31 & 2 & 1 & 65 & 1 & $71 \%$ \\
\hline G2 & 15050 & 17 & 3 & 1 & 25 & 3 & $60 \%$ \\
\hline G3 & 11400 & 27 & 3 & 1 & 70 & 3 & $66 \%$ \\
\hline
\end{tabular}

Table (2). Tumor nodules in liver of mice infected with secondary hydatid disease of sheep (G2) and human (G3) origin at 6 months post infection.

\begin{tabular}{|c|c|c|}
\hline Group & $\begin{array}{c}\text { No. of tumor } \\
\text { nodule/No. of cyst }\end{array}$ & $\begin{array}{c}\text { No. of tumor nodules } \\
\text { associated with no. of } \\
\text { animals }\end{array}$ \\
\hline G1 & - & - \\
\hline G2 & $12 / 8$ & $15 / 5$ \\
\hline G3 & $15 / 7$ & $15 / 2$ \\
\hline
\end{tabular}

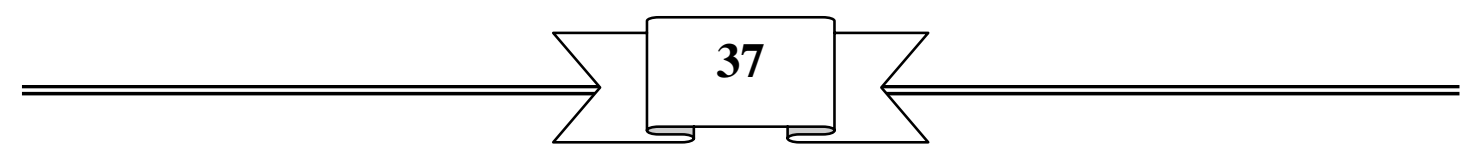



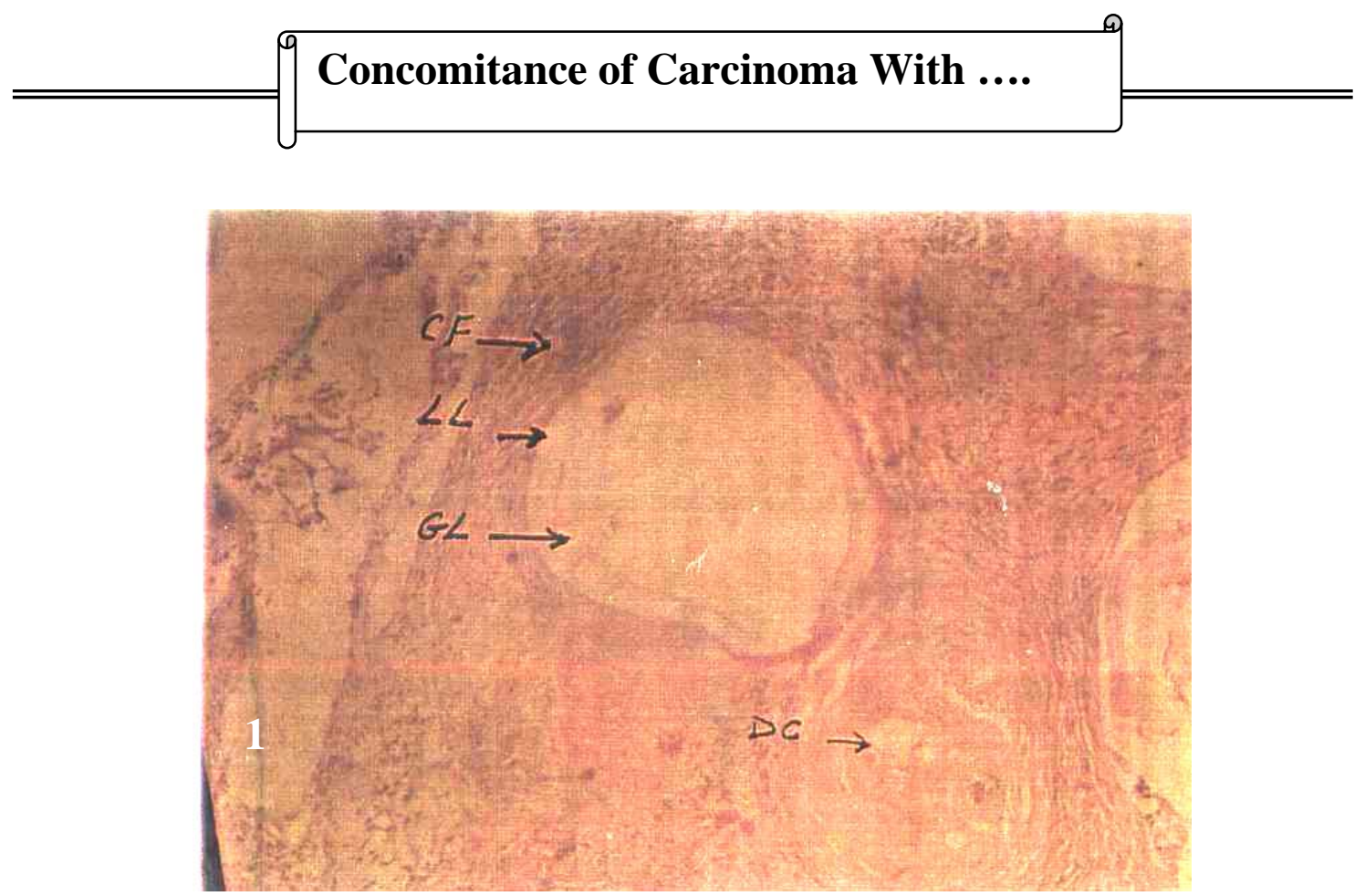

Fig. (1) Histomicrograph of hepatic tissue at 6 months post infection showing hydatid cysts containing daughter cysts (DC) surrounded by germial layer (GL), laminated layer (LL) and thick layer of collagen fibers (CF) with infiltration of mononuclear inflammatory cells. Stain hematoxylin-eosin 100X.

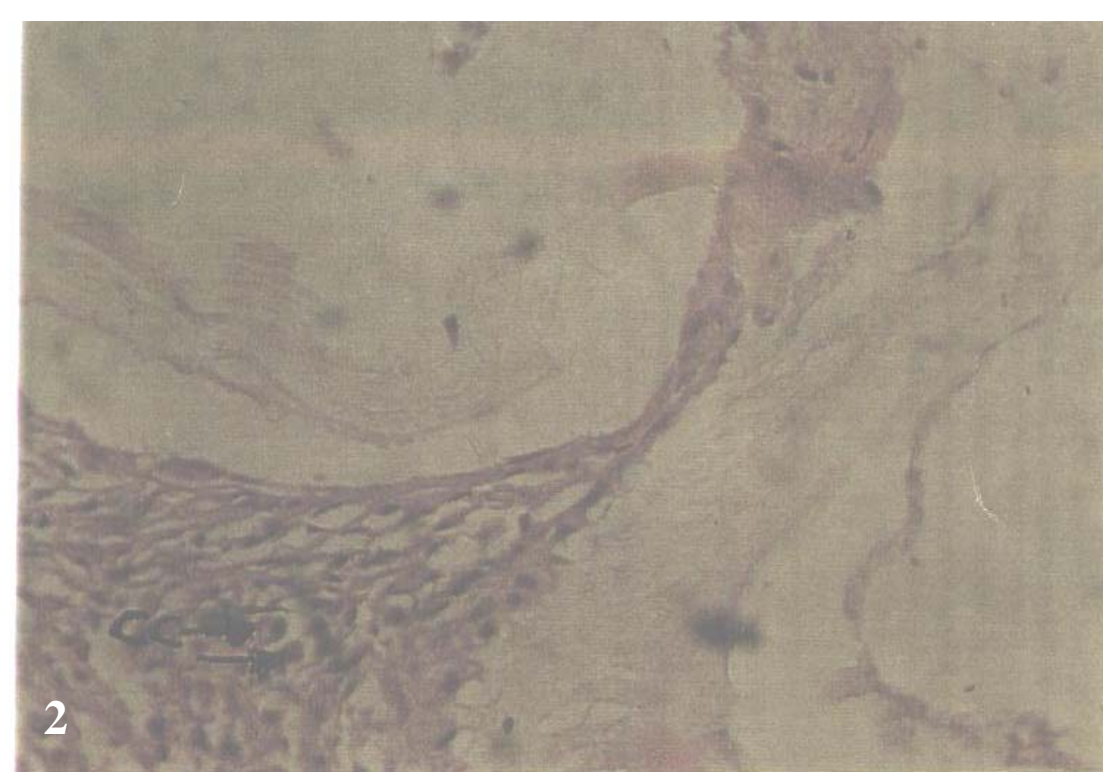

Fig. (2) Histomicrograph of hepatic tissue in portal area showing infiltration of cancer cells (CC) through the fibrous tissue surrounding the cyst. Stain hematoxylin-eosin 400X.

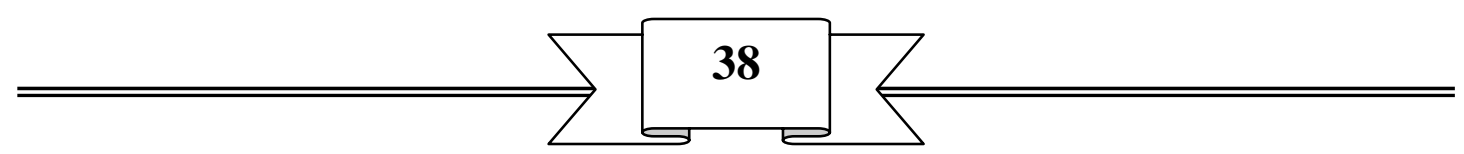



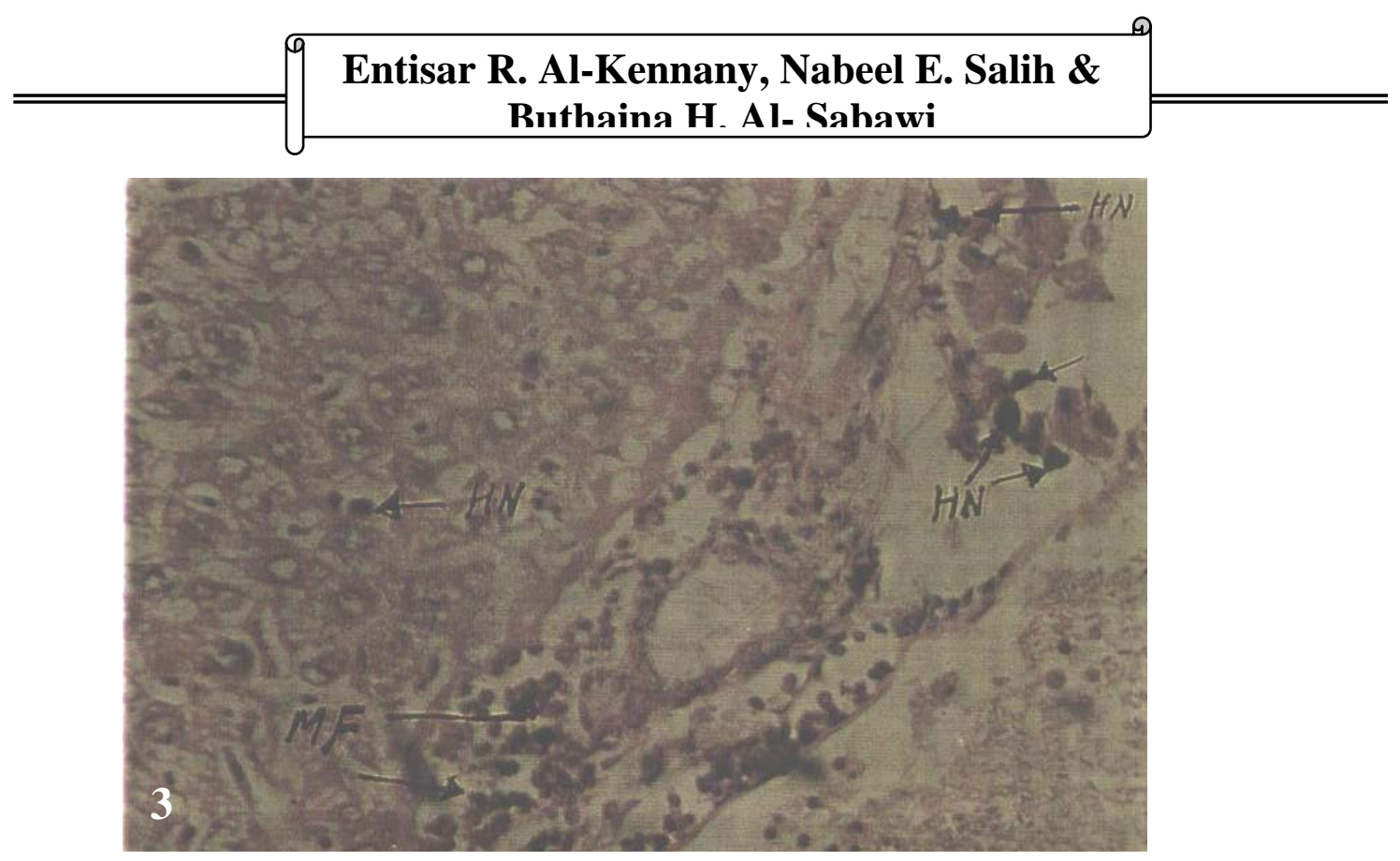

Fig. (3) Histomicrograph of hepatic tissue in portal area showing vacuolar degeneration in the cytoplasm of hepatic cells, hyperchromatic nuclei (HN) of cancer cells and mitotic figure (MF) in these nuclei. Stain hematoxylin-eosin 400X.

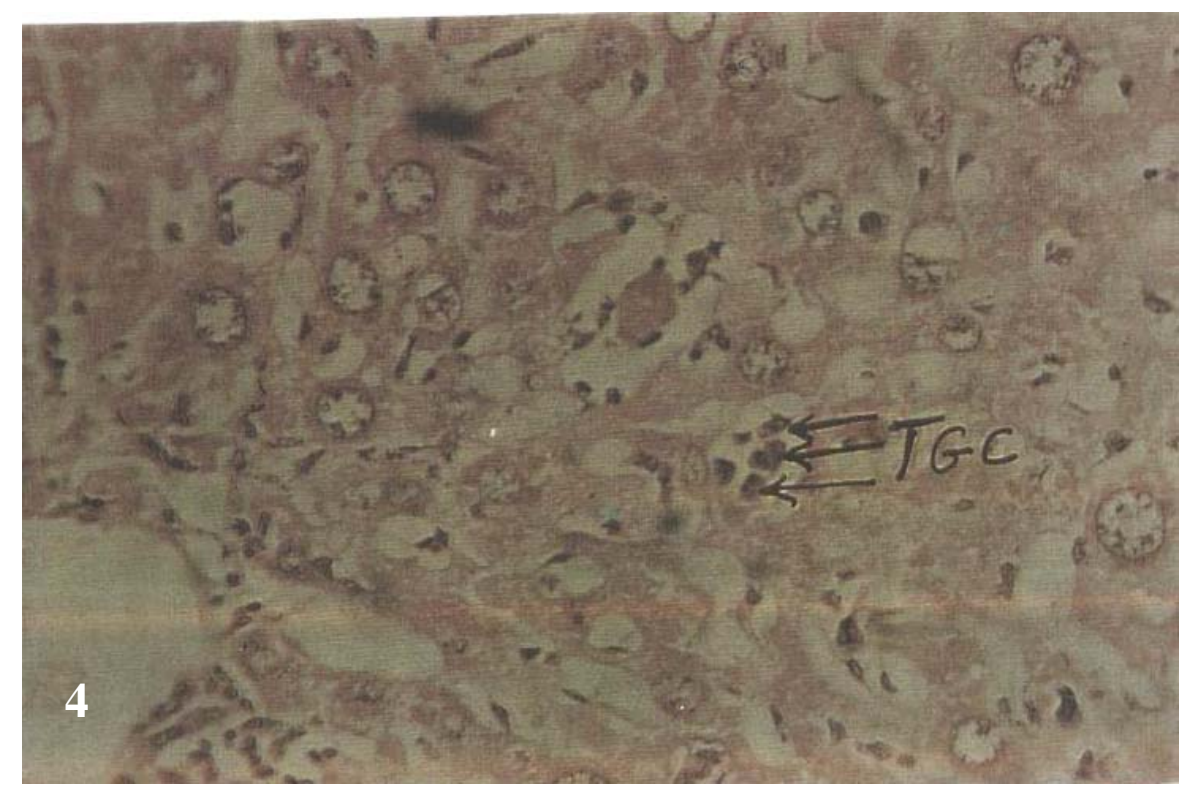

Fig. (4) Histomicrograph of hepatic tissue showing changes of carcinoma: tumor giant cells (TGC), vacuolation in cytoplasm of hepatocytes, mitotic figure of nuclei and dilatation of sinusoids. Stain hematoxylin-eosin 400X.

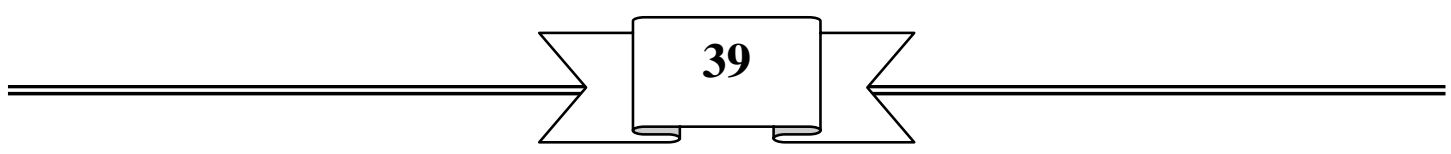




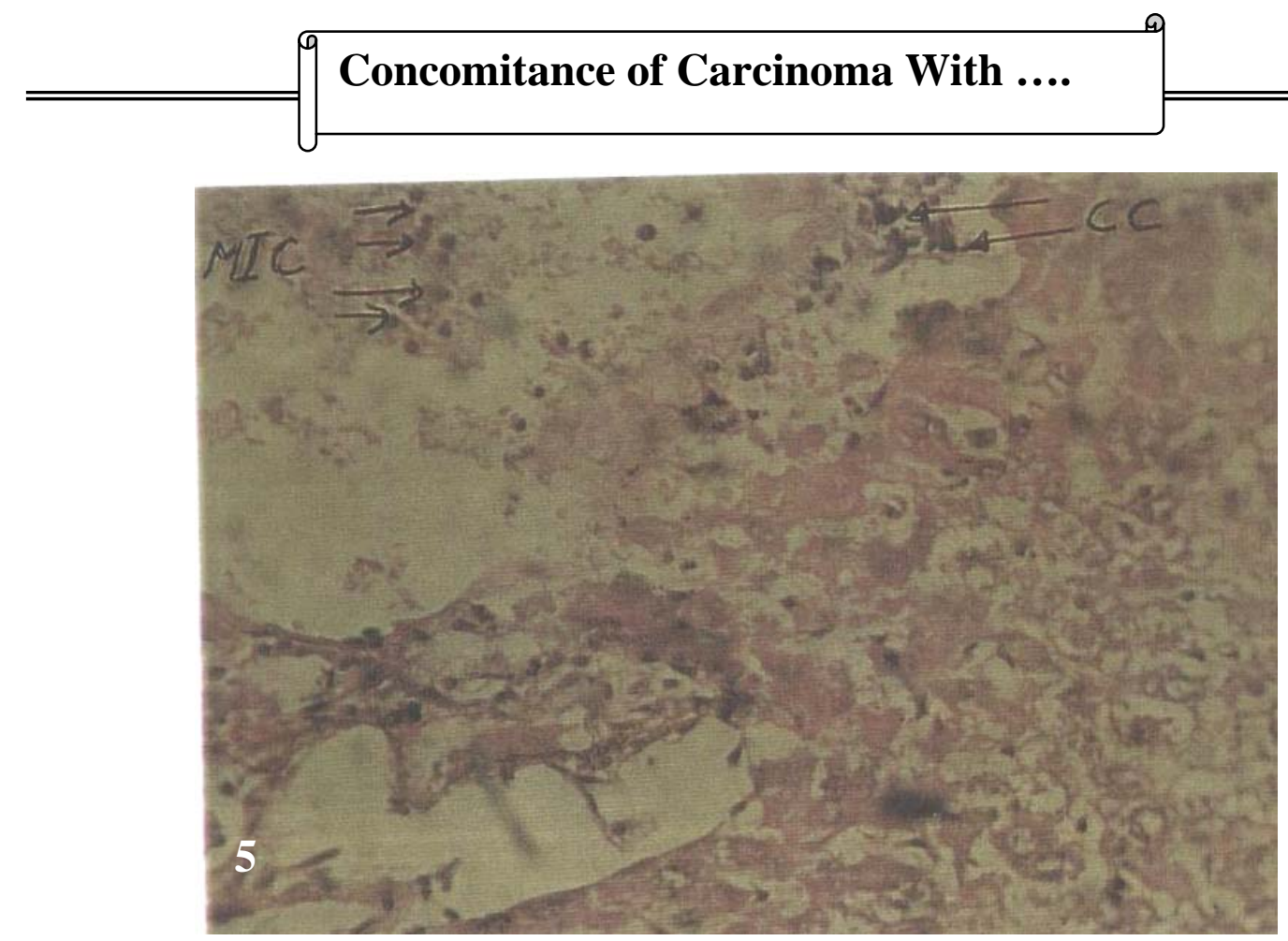

Fig. (5) Histomicrograph of hepatic tissue showing central necrosis of hepatocytes, cancer cells (CC) with infiltration of mononuclear (MIC) inflammatory cells and vacuolation of cytoplasm of hepatocytes. Stain hematoxylin-eosin 400X.

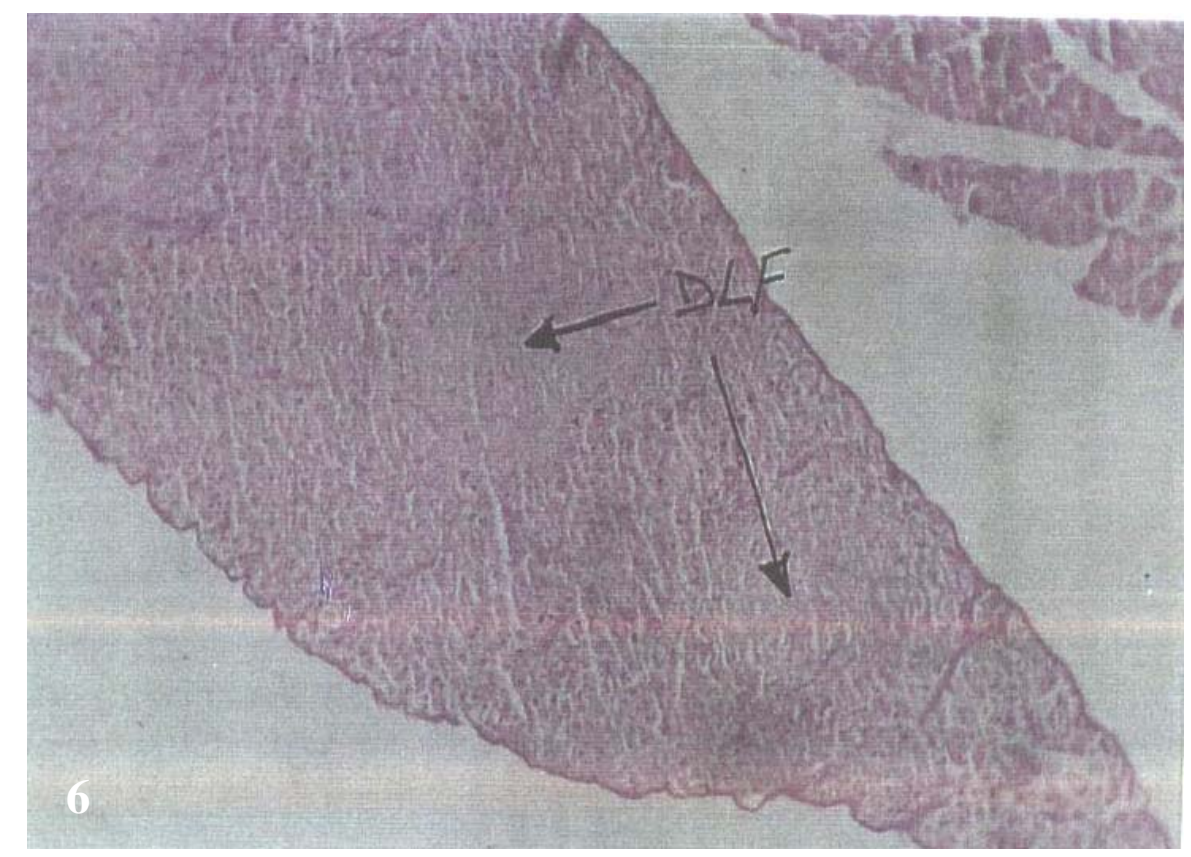

Fig. (6) Histomicrograph of spleen showing deplesion of lymphoid follicles (DLF), presence of tumor cells in the interstitial tissues. Stain hematoxylin-eosin 10X.

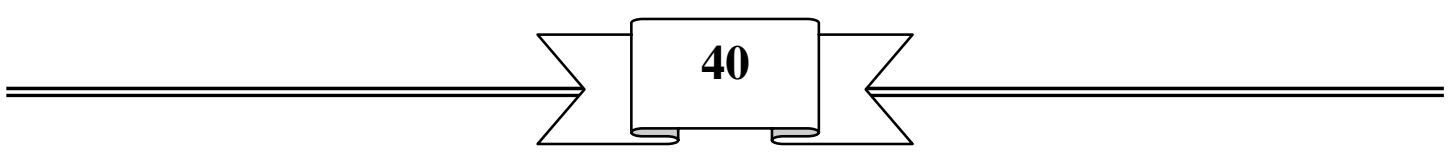



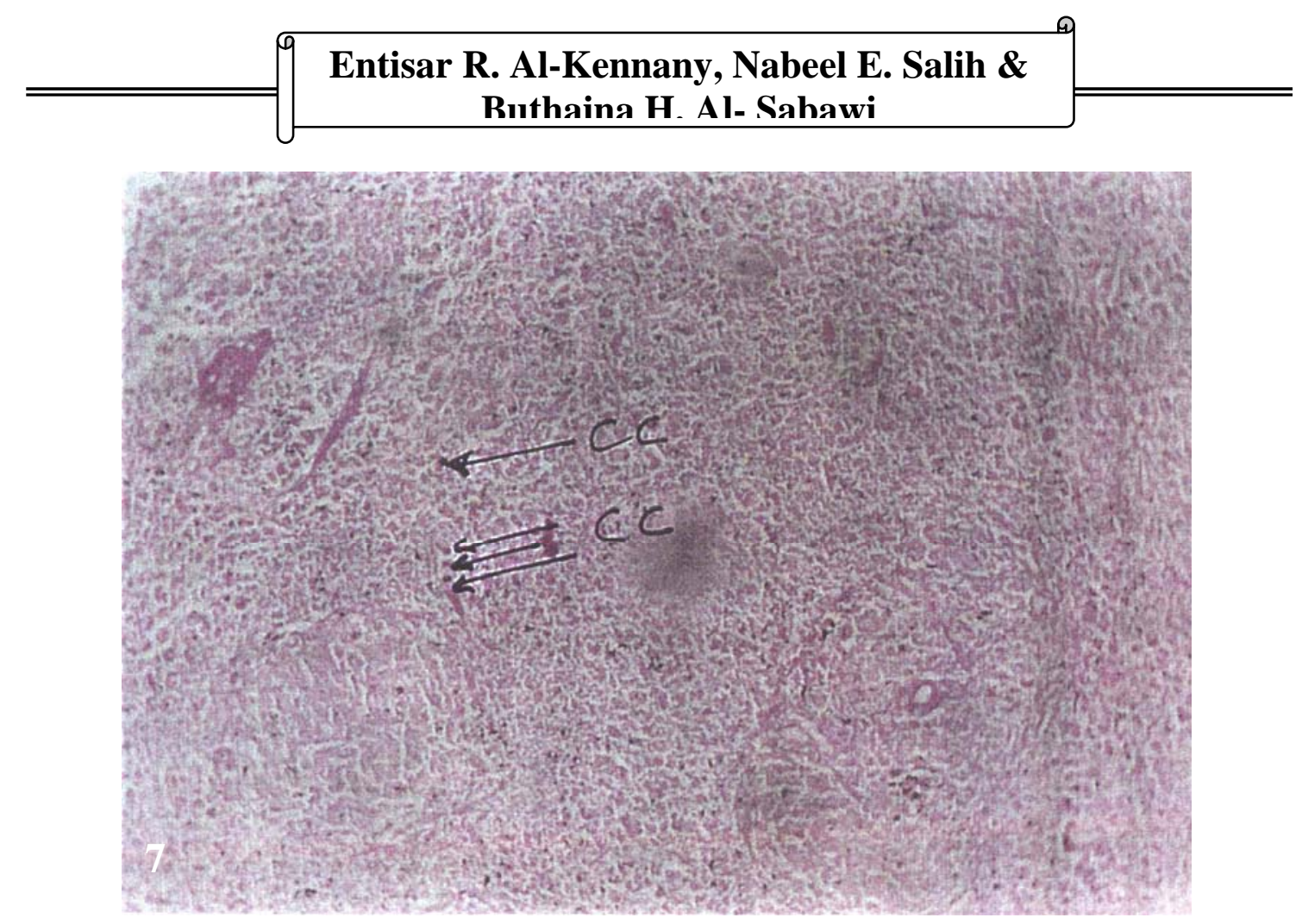

Fig. (7) Histomicrograph of spleen showing presence of tumor cells with hyperchromatic nuclei. Stain hematoxylin-eosin 40X.

\section{REFERENCES}

1. Andersen F.L., Ouhelli H. and Kachani M. " Compendium on Cystic Echinococcosis". Brigham Young University Print Services, UT 84604 (1997).

2. Smyth J.D., "Changing concepts in the microecology, macroecology and epidemiology of hydatid disease": Geerts C, Kumar V, Brandt J (Eds.): Helminth Zoonoses. Martinus Nijhoff Publishers(1987).

3. Sarciron M.E., Walbaum S., Arsac C., Raynaud G. and. Petavy A.F., Am. J. Trop. Med. Hyg., 48 (5): 658-665(1993).

4. Sarciron M.E., Walbaum S. and Petavy A.F., Riv. Parassit. 81: 329333 (1995).

5. Al-Sanafi A.E., Ph. D. Thesis, College of Medicine, University of Baghdad, Iraq (1996).

6. Roberts L.S., and Janovy J., Foundations of Parasitology. $6^{\text {th }}$ ed. McGrow Hill. London (2000).

7. Smyth J.D., In vitro culture of Echinococcus spp. Proc. $13^{\text {th }}$ Int. Cong. Hydatid. Madrid :84-95 (1985).

8. Smyth J.D., and Barrett N.J., Trans. Roy. Soc. Trop. Med. Hyg., 74: 649 - 652 (1980).

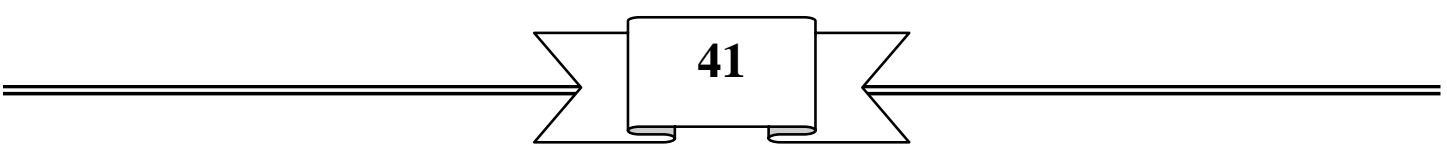


9. Drury R.A.B., and Wallington E.A., Cartton's histological technique. $5^{\text {th }}$ ed. Oxford University Press (1983).

10.Park P.H., Fikrig S.M. and Smithwick E.M., Lancet. 2: 532-534 (1968).

11.Riley E.M., Dixon J.B., Jenkins P. and Ross G., Ann. Trop. Med. Parasitol., 78:210-212(1986).

12.Belding D.L., Textbook of Parasitology. $3^{\text {rd }}$ ed. Appleton Century Crofts (1965).

13.Janssen D., Rueda M.C., DeRycke P.H. and Osuna., Parasit. Immunol. 19:149-160 (1997).

14.Salih N.E., and Abbu O.A.N., Riv. Parassit., 18 (62):217-223 (2001).

15.Salih N.E., and Abbu O.A.N., Riv. Parassit. Vol. XX (LXIII), N. (3):167-182(2002).

16.Shepherd J.C., and McManus D.P., Mol. Biochem. Parasitol., 25: 143-154 (1987).

17.Sulquet C., Green-Edwards C. and Leid R.W., Int. J. Parasitol. 14:165172(1984).

18.Lightowlers M.W., Int. J. Parasitol. 20: 471-478 (1990).

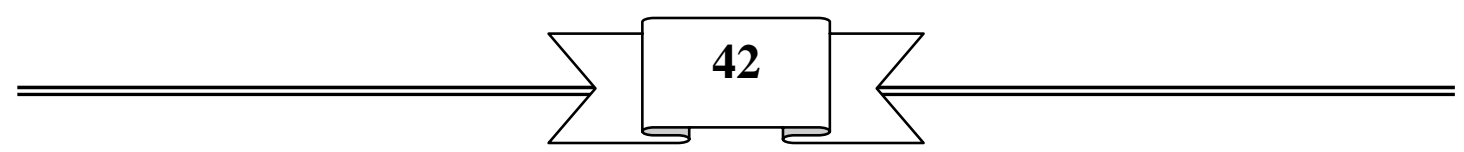

